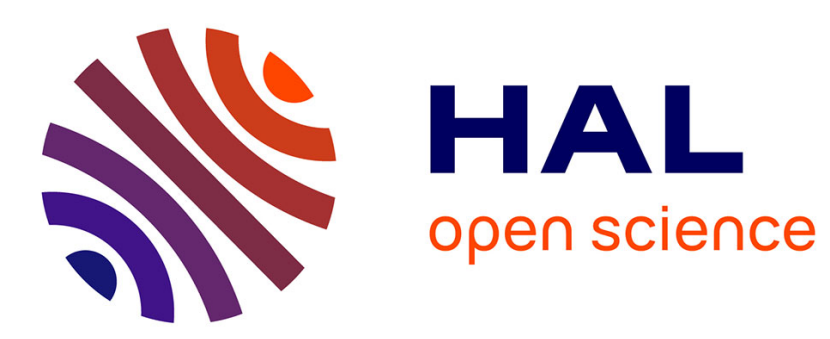

\title{
High efficacy of extracts of Cameroon plants against tomato late blight disease
}

P. Goufo, C. Teugwa Mofor, D.A. Fontem, D. Ngnokam

\section{To cite this version:}

P. Goufo, C. Teugwa Mofor, D.A. Fontem, D. Ngnokam. High efficacy of extracts of Cameroon plants against tomato late blight disease. Agronomy for Sustainable Development, 2008, 28 (4), pp.567-573. hal-00886482

\section{HAL Id: hal-00886482 \\ https://hal.science/hal-00886482}

Submitted on 1 Jan 2008

HAL is a multi-disciplinary open access archive for the deposit and dissemination of scientific research documents, whether they are published or not. The documents may come from teaching and research institutions in France or abroad, or from public or private research centers.
L'archive ouverte pluridisciplinaire HAL, est destinée au dépôt et à la diffusion de documents scientifiques de niveau recherche, publiés ou non, émanant des établissements d'enseignement et de recherche français ou étrangers, des laboratoires publics ou privés. 


\title{
High efficacy of extracts of Cameroon plants against tomato late blight disease
}

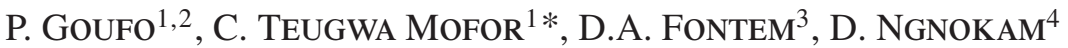 \\ ${ }^{1}$ Faculty of Science, University of Yaounde I, PO Box 812 Yaounde, Cameroon \\ ${ }^{2}$ College of Agriculture, South China Agricultural University, 510642 Guangzhou, China \\ ${ }^{3}$ Faculty of Agriculture, University of Dschang, PO Box 208 Dschang, Cameroon \\ ${ }^{4}$ Faculty of Science, University of Dschang, PO Box 67 Dschang, Cameroon
}

(Accepted 12 June 2008)

\begin{abstract}
The classical protection of tomato plants against the late blight disease caused by the fungi Phytophthora infestans involves the use of synthetic fungicides. However, such a practice raises two major issues. First, synthetic fungicides are toxic substances that are a threat to the ecosystem. Second, the efficiency of synthetic fungicides is decreasing due to the development of fungicide resistance by the fungi. In addition, there is growing concern from consumers about food contamination due to heavy reliance on toxic and persistent chemicals in plant protection strategies. Therefore, there is a necessity to evaluate the efficacy of alternative compounds. Biologically active products occur in plants for protection against pests, pathogens and other plants. Such compounds could be valuable as biopesticides for controlling plant diseases because they are biodegradable and selective in their activities. In that context, we conducted laboratory and greenhouse experiments to assess the efficacy of nine extracts of native plants of Cameroon in controlling P. infestans. Sporangial germination was determined after $24 \mathrm{~h}$ of incubation on $1.5 \%$ water agar medium at $18{ }^{\circ} \mathrm{C}$ in the dark. Lesion size, and late blight latency and severity were assessed on 7-8-week-old detached leaflets and whole tomato plants incubated in the greenhouse for 7 days. Our results showed that Cupressus benthamii and Vetiveria zizanioides extracts were the most effective preparations, leading to $23 \%$ and $35 \%$ inhibition of sporangial germination, respectively, and to $86 \%$ and $77 \%$ disease reduction. A clear relationship between disease latency and disease severity was established. The identification of $C$. benthamii and $V$. zizanioides extracts as potential alternate compounds for late blight control is a major step in the process of replacing harmful pesticides. Using these biopesticides in combination with other established disease management practices could help control late blight in a more sustainable and environmentally friendly way.
\end{abstract}

plant extracts / Phytophthora infestans / late blight / tomato / antifungal activity / disease suppression / biopesticide

\section{INTRODUCTION}

Phytophthora infestans (Mont) de Bary, the causal agent of late blight, is the most devastating pathogen in potatoes and tomatoes worldwide. P. infestans left its footprint in human history when in the 19th century it was responsible for the Irish potato famine (Erwin and Ribeiro, 1996). This pathogen causes defoliation and blight of leaves, potato tubers and tomato fruits. Epidemics of late blight happen with high intensity in practically all the areas where potato and tomato are grown, especially during the wet season and rainy weather. $P$. infestans usually requires low temperatures for development, the optimum temperature and relative humidity being $18-22{ }^{\circ} \mathrm{C}$ and $100 \%$, respectively (Erwin and Ribeiro, 1996). Because temperatures are generally low in tropical areas, yield

* Corresponding author: cteugwa@yahoo.fr losses caused by late blight can be very high when control measures are not appropriately adopted, and have been estimated to be as high as $71 \%$ in potato and $100 \%$ in tomato in Cameroon (Fontem et al., 2005).

Tomato growers mainly rely upon intensive fungicide application to control late blight, which results in the development of fungicide resistance by the pathogen and toxicity to the environment (Winteringham, 1985; Strange, 2003). Protective sprays of Ridomil Plus ( $12 \%$ metalaxyl $+60 \%$ cuprous oxide) and maneb are widely used to control late blight in Solanaceous crops in Cameroon. As a consequence, there are currently only a few tomato and potato varieties that are moderately resistant to late blight. Metalaxyl resistance has been observed in Cameroon (Fontem et al., 2005) and elsewhere (Lee et al., 1999; Mukalazi et al., 2001). Other control measures such as cultural and physical methods have been found to be of low efficiency, high cost and difficult to implement in an 
Table I. List and characteristics of plant species collected in the western highlands of Cameroon during 2004, extracted in a mixture of methylene chloride and methanol (1:1 vol/vol) and used to assess fungitotoxicity on Phytophthora infestans.

\begin{tabular}{|c|c|c|c|c|}
\hline Botanical name & $\begin{array}{l}\text { Common } \\
\text { name }\end{array}$ & Family & $\begin{array}{l}\text { Part } \\
\text { used }\end{array}$ & Description \\
\hline Cupressus benthamii Endl. & $\begin{array}{c}\text { Mexican } \\
\text { cypress }\end{array}$ & Cupressaceae & Leaves & Tree $(25-30 \mathrm{~m})$ \\
\hline $\begin{array}{l}\text { Pachypodanthium staudtii Engl. } \\
\text { and Diels }\end{array}$ & Deguetia & Annonaceae & Bark & Tree $(18-28 \mathrm{~m})$ \\
\hline Dracaena deisteliana Engl. & Peace tree & Dracaenaceae & Leaves & Shrub $(0.5-3.5 \mathrm{~m})$ \\
\hline $\begin{array}{l}\text { Erigeron floribundus (Kunth) } \\
\text { Sch.Bip }\end{array}$ & $\begin{array}{l}\text { Broadleaf } \\
\text { Fleabane }\end{array}$ & Compositae & Leaves & $\operatorname{Herb}(0.03-0.2 \mathrm{~m})$ \\
\hline Vetiveria zizanioides (L). Nash & Vetiver grass & Graminae & Roots & Grass $(0.5-1.5 \mathrm{~m})$ \\
\hline $\begin{array}{l}\text { Croton macrostachyus Hochst. ex } \\
\text { Fer. and Gal }\end{array}$ & $\begin{array}{l}\text { Broad-leaved } \\
\text { Croton }\end{array}$ & Euphorbiaceae & Leaves & Tree $(6-12 \mathrm{~m})$ \\
\hline Lantana camara $\mathrm{L}$ & Lantana & Verbenaceae & Leaves & Shrub $(0.8-1.8 \mathrm{~m})$ \\
\hline $\begin{array}{l}\text { Hymenodictyon floribundum } \\
\text { (Steud. And Hochst.) BL Rob. }\end{array}$ & Fire bush & Rubiaceae & Leaves & Shrub (6-8 m) \\
\hline $\begin{array}{l}\text { Bryophyllum pinnatum (Lam.) } \\
\text { Oken }\end{array}$ & $\begin{array}{l}\text { Canterbury } \\
\text { bells }\end{array}$ & Crassulaceae & Leaves & Herb $(0.05-0.2 \mathrm{~m})$ \\
\hline
\end{tabular}

extensive area, especially in developing countries (Schippers, 2004).

Consequently, there is a need to screen alternative compounds for disease control, which is important for reduction of fungicide inputs and production costs. One alternative to synthetic fungicides is the use of plant-derived fungicidal products. The application of crude plant extracts for the control of pests and diseases in crop production systems is standard practice in most developing countries (Cutler, 1988; Dales, 1996) and various organic extracts from these regions were reported to possess differing levels of antimicrobial activities in vitro and in vivo against phytopathogenic fungi and bacteria (Ameziane et al., 2007; Montes-Molina et al., 2008). The main advantages of using these compounds include their availability and a broad spectrum of modes of action (Winteringham, 1985; Cutler, 1988; Regnault-Roger et al., 2005). Studies examining different Solanaceous crops have reported that essential oils and plant extracts are effective growth inhibitors of $P$. infestans. Quintanilla et al. (2002) demonstrated that the essential oil of Hyssopus officinalis could inhibit the mycelial growth of $P$. infestans and suppress late blight on potato plants in growth chambers. Extracts from Potentilla erecta, Salviae officinalis (Blaeser and Steiner, 1999; Dorn et al., 2007), Galla chinensis and Rheum rhabarbarum (Wang et al., 2007) have also shown promising effects against potato late blight.

Many plant-derived products exhibiting insecticidal, fungicidal, bactericidal and herbicidal effects have been reported in Cameroon. However, most studies dealing with these compounds were limited to in vitro tests and little is known about the efficacy of the compounds against $P$. infestans. Consequently, the objective of this work was to determine if extracts from native plants of Cameroon could inhibit the growth and reproduction of $P$. infestans. The activity of nine plant extracts was tested in vitro on sporangial germination of $P$. infestans and in vivo on late blight development on detached leaflets and entire tomato plants.

\section{MATERIALS AND METHODS}

All experiments were conducted during 2004 and 2005 at the Phytopathology Laboratory of the Faculty of Agriculture, the University of Dschang, Cameroon $\left(5^{\circ} 35^{\prime} \mathrm{N}, 10^{\circ} 05^{\prime} \mathrm{E}\right.$, $1400 \mathrm{~m})$.

\subsection{Collection of plant material, extraction and formulation}

Based on literature, folk legends and pilot studies examining the in vitro effects of plant-derived products on various pathogens (Burkill, 1985; Cable and Cheek, 1998), nine Cameroonian plants were selected (Tab. I), and identified at the National Botanical Center of Yaoundé, Cameroon, where a voucher specimen of each plant was deposited.

Plant leaves, roots and bark were collected in June 2004, air-dried $\left(25-27^{\circ} \mathrm{C}\right)$ for 10 days and weighed to determine dry matter content. They were then ground to obtain a fine powder and finally kept in plastic bags at room temperature for 10 to 30 days until used for extraction. For each plant, a $500 \mathrm{~g}$ sample of fine powder was extracted at $27^{\circ} \mathrm{C}$ for 1 week by putting in a mixture of methylene chloride and methanol $(1: 1 \mathrm{vol} / \mathrm{vol})$ at a ratio of 1:8 (wt/vol, dry powder/solvent). The extract was filtered through two layers of cheesecloth and vacuum-dried at 40 to $45^{\circ} \mathrm{C}$ to obtain a paste. The paste was weighed to determine the percentage of paste in the dry leaves, and then stored at room temperature for the 2004 and 2005 experiments. Extract solutions were prepared by dissolving $0.6 \mathrm{~g}$ of each paste in $20 \mathrm{~mL}$ Sterilized Distilled Water (SDW) containing $0.05 \%$ Tween 20 , and a concentration of $3 \%$ was obtained.

\subsection{Preparation of P. infestans inoculum}

The Phytophthora infestans isolate used in all trials was isolated from infected tomato leaves obtained from the field 
as described by Fontem et al. (2004), and identified by the phytopathology laboratory of the Plant Protection Department, University of Dschang, Cameroon. Cultures of $P$. infestans were grown on V8 medium amended with 150 ppm ampicillin and $100 \mathrm{ppm}$ rifamycin, in $90 \mathrm{~mm}$-diameter Petri dishes for $10-14$ days at $18{ }^{\circ} \mathrm{C}$ in the dark. The inocula were collected with a fine brush into $10 \mathrm{~mL}$ SDW containing $0.01 \%$ Tween 20. The suspensions were shaken in a vortex to dislodge sporangia, and then filtered through a double layer of cheesecloth to remove mycelial fragments. The sporangial suspension was transferred to another flask and the inoculum concentration was diluted to $2 \times 10^{4}$ sporangia/mL with the aid of a hemocytometer. The suspension was incubated at $8{ }^{\circ} \mathrm{C}$ for $1 \mathrm{~h}$ to promote zoospore release prior to use.

\subsection{Inhibition of $P$. infestans sporangial germination}

The effect of the plant extracts was evaluated in comparison with two synthetic fungicides, Ridomil Plus 72 WP (12\% metalaxyl $+60 \%$ cuprous oxide, $0.33 \%$ concentration) and Plantineb $80 \mathrm{WP}$ ( $80 \%$ maneb, $0.66 \%$ concentration), that are commonly used in tomato late blight management in Cameroon (Fontem et al., 2005). An extract concentration of 3\% was used in the study. Experiments were set up in a completely randomized design with four replications.

Mixtures (1:1, $20 \mu \mathrm{L}$ of sporangial suspension of $P$. infestans and $20 \mu \mathrm{L}$ of each extract) were prepared and dropped on wet Whatman paper deposited on slides. $20 \mu \mathrm{L}$ of SDW containing $0.05 \%$ Tween 20 and $20 \mu \mathrm{L}$ spore suspension served as a control treatment. The Whatman paper was then taken from the slide and placed in the center of a $90 \mathrm{~mm}$-diameter plate containing $1.5 \%$ water agar medium. A total of four Petri dishes (replications) was used for the experiment and they were put in an incubator at $18{ }^{\circ} \mathrm{C}$ in the dark. After $24 \mathrm{~h}$, a fragment of water agar with the Whatman paper containing the sporangia on the upper side was transferred to a microscope slide, colored with a drop of lactopherol and covered with a coverslip for microscopic examination. The number of germinated and non-germinated sporangia was counted on 200 sporangia/slide. The inhibitory effect of the extracts against $P$. infestans was estimated based on percent germination rate and calculated according to the formula $\% \mathrm{G}=(\mathrm{Gg} / \mathrm{Gt}) 100$, where $\mathrm{Gg}$ is the number of germinated sporangia and $\mathrm{Gt}$ the total number of sporangia. The experiment was conducted in 2004 and repeated three times.

\subsection{Inhibition of $P$. infestans on detached leaflets}

Late blight of tomato was used as a model system for in vivo studies. The soil type was typic paleustult (dystric nitrosol, $\mathrm{pH}-\mathrm{H}_{2} \mathrm{O}$ 5.0; CEC $33 \mathrm{meq} / 100 \mathrm{~g}$ soil; 13:35:52 sand/loam/clay). Seeds of the tomato cultivar "Roma VF" obtained from a local shop in Dschang served to produce sensitive host plants for $P$. infestans. The nursery bed was fertilized with $2 \mathrm{~g} / \mathrm{m}^{2}$ urea before sowing. Seedlings were transplanted after 4 weeks when plants had developed 4-5 true leaves and dispensed into 11 plastic pots that were transferred to the greenhouse. A foliar fertilizer, Manvert 8-8-6 (3 mL/pot), was applied on leaves.

Fully mature healthy leaflets were detached from the middle canopy layer of 7-8-week-old plants raised in a greenhouse. The detached leaves were washed with SDW and the base of each leaflet was covered with a piece of moist cotton to reduce leaf desiccation. Single leaflets were then placed upside down (abaxial surface up) in four $90 \mathrm{~mm}$-diameter Petri dishes containing moistened filter paper to form a humidity chamber. The experiment was in a completely randomized design with four replicates.

Plant extracts at $3 \%$ were applied on detached leaflets by means of a small paint brush. After the leaflets had dried $(1 \mathrm{~h})$ they were then inoculated using the method described by Mukalazi et al. (2001). One drop (50 $\mu \mathrm{L}, 2 \times 10^{4}$ spores $\left./ \mathrm{mL}\right)$ of sporangial suspension was applied to the midrib of the leaflet using a Pasteur pipette. Control treatments contained a drop of SDW containing $0.05 \%$ Tween 20 and were also inoculated. Untreated and non-inoculated leaflets served as blank controls. The Petri dishes were kept in the greenhouse under a $12 \mathrm{~h}$ photoperiod. The average temperature in the greenhouse was $21{ }^{\circ} \mathrm{C}$ during the day and $18{ }^{\circ} \mathrm{C}$ during the night. After 7 days of incubation, lesion size $\left(\mathrm{cm}^{2}\right)$ was measured using the formula: $\mathrm{S}=\pi(\mathrm{L}+1)^{2} / 4$, where $\mathrm{L}(\mathrm{cm})$ and $1(\mathrm{~cm})$ are the length and width of the lesion for each detached leaflet, respectively (Fontem et al., 2004). The experiment was conducted two times in 2004, and a second trial similar to that described above was carried out in 2005.

\subsection{Inhibition of $P$. infestans under greenhouse conditions}

Forty-day-old tomato plants raised in the greenhouse were used for the experiment. Plants were thinned to one plant per pot and a whole plant constituted an experimental unit. The experiment was conducted in 2004 and 2005 in a complete randomized block design with four replicates, one plant per replicate. Treatments were applied by spraying the extract solution (3\% concentration) on all aerial surfaces of the tomato leaves to run-off, using a handheld sprayer. At about $1 \mathrm{~h}$ after treatment when the leaves had dried, the inoculum suspension was sprayed on all the leaves $(1 \mathrm{~mL} / \mathrm{leaf})$ using a handheld sprayer. Control treatments included plants inoculated after treatments with Ridomil Plus, Plantineb and SDW containing $0.05 \%$ Tween 20. Untreated and non-inoculated plants served as blank controls. After inoculation, plants were allowed to dry, then covered with a polyethylene bag for $24 \mathrm{~h}$ to maintain the high humidity atmosphere around the leaves and immediately placed in the greenhouse for 7 days at $21^{\circ} \mathrm{C}$ during the day and $18{ }^{\circ} \mathrm{C}$ during the night, with a $12 \mathrm{~h}$ photoperiod.

The plants were observed daily for first symptoms (incubation period) and first sporulation (latent period). After the appearance of symptoms, late blight severity (proportion of leaf area infected) was estimated visually on each plant with the aid of the modified Horsfall-Barratt rating scale of 1 to 
Table II. Phytophthora infestans sporangial germination and late blight severity on detached leaflets and whole tomato plants after treatment with various plant extracts at 3\%. Sporangial germination was determined after $24 \mathrm{~h}$ of incubation on a Whatman paper placed on $1.5 \%$ water agar medium at $18{ }^{\circ} \mathrm{C}$ in the dark. Lesion size and late blight severity were assessed on 7-8-week-old detached leaflets in Petri dishes and whole tomato plants, respectively. Petri dishes and entire tomato plants were incubated in the greenhouse for 7 days with an average temperature of $21{ }^{\circ} \mathrm{C}$ during the day and $18{ }^{\circ} \mathrm{C}$ during the night, with $12 \mathrm{~h}$ day/light. Ridomil Plus $(0.33 \%)$ and Plantineb $(0.66 \%)$ were used as positive controls. Means in a column followed by the same letter are not significantly $(P<0.05)$ different according to Tukey's HSD multiple comparison test. SDW $=$ sterilized distilled water, NA $=$ not available because of phytotoxic effects, - No phytotoxicity observed, + Phytotoxicity observed (burning or chlorosis) during the 7 day observation period on tomato leaves.

\begin{tabular}{lccccc}
\hline Treatment & $\begin{array}{c}\text { Sporangial } \\
\text { germination } \\
(\%)\end{array}$ & $\begin{array}{c}\text { Lesion } \\
\text { size } \\
\left(\mathrm{cm}^{2}\right)\end{array}$ & $\begin{array}{c}\text { Disease } \\
\text { severity } \\
(\%)\end{array}$ & $\begin{array}{c}\text { Phytotoxic } \\
\text { effects }\end{array}$ & $\begin{array}{c}\text { \%Paste } \\
\text { yield } \\
\text { (wt/wt) }\end{array}$ \\
\hline Dracaena deisteliana & $66 \mathrm{~cd}$ & $21 \mathrm{ab}$ & $40 \mathrm{~b}$ & - & 24 \\
Cupressus benthamii & $64 \mathrm{~d}$ & $2 \mathrm{e}$ & $8 \mathrm{e}$ & - & 9 \\
Pachypodanthium staudtii & $48 \mathrm{f}$ & $20 \mathrm{ab}$ & $56 \mathrm{a}$ & - & 12 \\
Erigeron floribundus & $85 \mathrm{a}$ & $13 \mathrm{~cd}$ & $30 \mathrm{~cd}$ & - & 8 \\
Vetiveria zizanioides & $54 \mathrm{e}$ & $1 \mathrm{efg}$ & $13 \mathrm{e}$ & - & 15 \\
Croton macrostachyus & $67 \mathrm{~cd}$ & $15 \mathrm{~cd}$ & $33 \mathrm{bc}$ & - & 13 \\
Lantana camara & $63 \mathrm{~d}$ & $\mathrm{NA}$ & $24 \mathrm{~d}$ & + & 7 \\
Hymenodictyon floribundum & $70 \mathrm{bc}$ & $16 \mathrm{bc}$ & $24 \mathrm{~d}$ & + & 4 \\
Bryophyllum pinnatum & $73 \mathrm{~b}$ & $11 \mathrm{~d}$ & $33 \mathrm{bc}$ & - & 6 \\
Plantineb & $25 \mathrm{~g}$ & $1 \mathrm{ef}$ & $3 \mathrm{f}$ & - & - \\
Ridomil Plus & $23 \mathrm{~g}$ & $0 \mathrm{fg}$ & $0 \mathrm{~g}$ & - & - \\
SDW with 0.05\% Tween 20 & $83 \mathrm{a}$ & $23 \mathrm{a}$ & $57 \mathrm{a}$ & $\mathrm{g}$ & - \\
Non-inoculated control & & $0 \mathrm{~g}$ & $0 \mathrm{~g}$ & \\
\hline
\end{tabular}

$12(1=0 \%, 12=100 \%$ disease severity $)$ (Berger, 1980). The experiment was repeated once.

The phytotoxicity of all test compounds was assessed visually in the greenhouse.

\subsection{Data analysis}

All statistical analyses were performed using SPSS (SPSS version 15.0, Chicago, IL). Data were transformed using the arcsine square root $(\mathrm{x} / 100)$ transformation for percent sporangial germination and disease severity, and square root $(\mathrm{x}+0.5)$ transformation for lesion size. Analysis of variance (ANOVA) tests were performed on data to test for significant $(P<0.05)$ differences between treatment effects of compounds for three factors: spore germination, inhibition of $P$. infestans on detached tomato leaflets and disease severity in the greenhouse. ANOVA was also performed to test for significant $(P<0.05)$ differences between the 2004 and 2005 experiments. Tukey's honest significant difference (HSD) multiple comparison tests were used to segregate treatments which were significantly different.

\section{RESULTS AND DISCUSSION}

In this study, in vitro, detached leaflet and whole tomato plant testing systems were used to assess the fungitoxicity of nine plant extracts from Cameroon on $P$. infestans development. The three experiments were conducted in 2004, and the detached leaflet and whole tomato plant tests were repeated in 2005. There were no significant $(P<0.05)$ differences between 2004 and 2005 results. Therefore, data from both experiments measuring late blight severity were pooled for analysis.

\subsection{Inhibition of $P$. infestans sporangial germination}

The results of the in vitro test assessing the sporangial germination of $P$. infestans as affected by different treatments at $3 \%$ after $24 \mathrm{~h}$ of incubation on a Whatman paper deposited on $1.5 \%$ water agar medium at $18{ }^{\circ} \mathrm{C}$ in the dark are presented in Table II. The nine preparations differed in their ability to control $P$. infestans; however, none of the compounds completely inhibited the sporangial germination of the pathogen. There was no significant $(P<0.05)$ difference between the germination rates of $P$. infestans grown on $E$. floribundus extractamended media (85\%) and those in the control treated with SDW (83\%). P. staudtii and V. zizanioides extracts showed the strongest inhibition of spore germination amongst all the tested plant extracts. The percentage of the germinated sporangia for the two extracts was $48 \%$ and $54 \%$, respectively. $V$. zizanioides is a densely tufted grass, found throughout the plains and valleys of the western highlands of Cameroon, but also found in the forest and savannah regions of the country. The plant is also cultivated by local populations who use it for headache, toothache, rheumatism, epilepsy, fever, burns and other medicinal purposes (Burkill, 1985; Cable and Cheek, 1998). The essential oil obtained from $P$. staudtii has been shown to completely inhibit mycelial growth of Alternaria solani, the causal agent of early blight of tomato and potato. 2,4,5-Trimethoxystyrene obtained from $P$. staudii has also been reported to reduce adult survival of the bruchid beetle Acanthoscelides obtectus and to cause total mortality of Callosobruchus maculatus infecting cowpea and Sitophilus zeamais infecting maize after 72 and $120 \mathrm{~h}$ of treatment, respectively (Kouna and Bouda, 2004). These results agree with the level of inhibition of growth observed in the present study. H. floribundum ( $70 \%$ germination rate) and B. pinnatum $(73 \%$ 
germination rate) extracts were less effective in inhibiting sporangial germination, while the other extracts did not differ in their activities, with germination rates ranging from $63 \%$ to 73\%. Overall, V. zizanioides and P. staudtii extracts showed the strongest inhibition of sporangial germination, followed by C. benthamii and L. camara extracts.

\subsection{Inhibition of $P$. infestans on detached leaflets}

When $P$. infestans inoculum was applied to detached leaflets of tomato in Petri dishes, no late blight lesions developed on leaflets treated with the synthetic fungicide Ridomil Plus after 7 days at $21{ }^{\circ} \mathrm{C}$ day and $18{ }^{\circ} \mathrm{C}$ night temperatures, with a $12 \mathrm{~h}$ photoperiod (Tab. II). A significant effect comparable with that of Ridomil Plus and Plantineb was obtained with $V$. zizanioides and $C$. benthamii extracts, with $1 \mathrm{~cm}^{2}$ and $2 \mathrm{~cm}^{2}$ lesion sizes, respectively. There were no significant $(P<0.05)$ differences between the inhibitory effects of B. pinnatum, E. floribundus, C. macrostachyus and H. floribundum extracts, with a lesion size range of $11 \mathrm{~cm}^{2}$ to $16 \mathrm{~cm}^{2}$. $P$. staudtii and $D$. deisteliana extracts did not differ from the control treated with SDW. A number of metabolites obtained from the essential oil and solvent extracts of L. camara have been shown to possess useful biological activities (Ghisalberti, 2000); in the present study, we were unable to assess its antagonistic effect at the concentration of $3 \%$ because of phytotoxicity. However, it was ineffective in reducing late blight severity at a concentration of $2 \%$ (data not shown). The results obtained indicate that $V$. zizanioides and $C$. benthamii extracts provided the highest level of protection on detached tomato leaflets.

\subsection{Inhibition of $P$. infestans on whole tomato plants in the greenhouse}

The nine plant extracts were also tested for their ability to provide protection from $P$. infestans in entire tomato plants incubated in the greenhouse at $21{ }^{\circ} \mathrm{C}$ day and $18{ }^{\circ} \mathrm{C}$ night temperatures, with a $12 \mathrm{~h}$ photoperiod, for 7 days. Daily observation of plants showed no difference between incubation and latent periods. This is indicative of the design of the study, where data were collected after 1 day. It has been reported by Suassuna et al. (2004) that the latent period can vary between 1 and $23 \mathrm{~h}$ with Brazilian isolates of $P$. infestans. So, it can be speculated that differences would be more obvious if data are collected after every 5 or $10 \mathrm{~h}$. Under greenhouse conditions, leaves previously treated with extracts of $B$. pinnatum, $P$. staudtii and $H$. floribundum showed late blight symptoms after one day. Symptoms were characterized by brown lesions on leaves (Erwin and Ribeiro, 1996). The latent period was significantly $(P<0.05)$ longer for $C$. macrostachyus, $L$. camara, D. deisteliana and V. zizanioides ( $2-3$ days), and C. benthamii and $E$. floribundus (4 days). This is very important when assessing pathogen aggressiveness and establishing disease control measures. A prolonged latent period is an important component of partial resistance and is necessary to predict the timing and frequency of fungicide application (Strange, 2003;
Suassuna et al., 2004). No late blight symptoms were observed during 7 days of incubation on plants treated with Ridomil Plus, while Plantineb-treated plants produced the first symptoms after 5 days.

Late blight severity in plants treated with the different extracts was lower than in the control plants (57\%) after 7 days, except for P. staudtii extract (56\%) (Tab. II). This corresponds to results of other studies which have demonstrated the efficacy of natural products in reducing leaf infestation on potato and tomato by P. infestans (Blaeser and Steiner, 1999; Quintanilla et al., 2002; Dorn et al., 2007; Wang et al., 2007). None of the plant extracts controlled disease as well as Ridomil Plus and Plantineb. Of the nine extracts tested, $C$. benthamii and $V$. zizanioides extracts provided statistically significant $(P<0.05)$ disease reduction, with $8 \%$ and $13 \%$ disease severity, respectively. There was no difference in disease severity between $E$. floribundus, B. pinnatum, C. macrostachyus and D. deisteliana extracts $(34 \%-40 \%)$ or between L. camara and H. floribundun extracts (30\%). There were, however, phytotoxic effects observed in the greenhouse when L. camara and $H$. floribundum extracts were applied at the concentration of $3 \%$ and which could have masked disease severity (Tab. II). Nevertheless, it can be concluded that at the concentration of $3 \%$, the disease severity in plants treated with $C$. benthamii and $V$. zizanioides extracts was significantly less than that observed in the control.

Our results show that the ability of some extracts to control $P$. infestans differs according to the test method used. $P$. staudtii extract, for example, moderately retarded sporangial germination of $P$. infestans, but failed to control late blight progression in vivo. The mechanisms of action of fungicides are through a reduction of sporangia and zoospore formation and a restriction of host colonization (Erwin and Ribeiro, 1996; Strange, 2003). It appears that $P$. staudtii extract was ineffective in preventing host penetration by P. infestans. E. floribundus extract did not reduce sporangial germination, but extended the latent period and reduced disease severity. Late blight severity was significantly reduced in plants treated with C. benthamii extract, while the same extract had only a low direct antifungal property as detected in vitro. Some products are unique in that they do not directly affect the pathogen itself, but elicit a response from the host plant (Strange, 2003; Regnault-Roger et al., 2005). The positive effect obtained with $C$. benthamii and E. floribundus extracts could be the result of induced resistance and the induction of tomato plants to produce disease-fighting compounds. Similar mechanisms of action were reported in tomato using pen, an aqueous extract of the dry mycelium of Penicillium chrysogenum (Thuerig et al., 2006), indole-3-acetic acid, ethephon and fusicoccin (Christ and Mösinger, 1989), and in potato using unsaturated fatty acids in potato (Cohen et al., 1991). Disease suppression on detached leaflets was generally associated with disease suppression on whole tomato plants and negatively correlated with disease latency. This indicates that when testing the antimicrobial activity of new fungicides, detached leaf assays can be used for a quick analysis.

Plant extracts derived from $500 \mathrm{~g}$ dry leaves were weighed to obtain the percentage of extractable paste. The extraction 
process yielded 4-24\% paste for the various extracts (Tab. II). This high yield for some of the extracts and the availability of the plants may well fulfill the need for a suitable product for conventional and organic systems to combat destructive diseases of crops. V. zizanioides, for example, is grown by many people in Cameroon for medicinal purposes; all the plants used in this study are accessible and found throughout the western highlands of Cameroon, but also in the forest and the savannah areas. Our data also showed that the active ingredients are stable, since the paste extracts dissolved in methylene chloride/methanol kept their activity after storage for 8 to 12 months at room temperature. However, further studies need to be conducted to identify and extract the active principles involved in disease control. The potential of using combinations of the various extracts must also be examined as there may be synergistic interactions in the mixture, which is valuable for preventing or delaying the build-up of resistant fungi. There is also research needed in the area of their toxicology. Crop protection strategies, however, emphasize the practical application of such compounds and for that to be valid, one has to know the mode of action and how easy it is to scale up production so that it would be of practical use to local farmers. Our previous results showed poor yield and activity of water extracts obtained using the protocol described in this paper, against sporangial germination and mycelial growth of many plant diseases. Another water extraction method believed to achieve better results has been proposed by Wang et al. (2007) and is currently being investigated. There are currently very few effective formulations of biological agents commercially available and implemented as part of an integrated late blight management strategy. However, we believe this is possible and can be achieved.

\section{CONCLUSION}

This study shows that there is a potential for developing natural fungicides based on plant-derived products for late blight control. Of the nine plant extracts tested, eight provided a level of disease control that was significantly different from that of tomato plants treated with only sterilized distilled water. Cupressus benthamii and Vetiveria zizanioides extracts were the most effective in reducing spore germination of $P$. infestans (23 and 35\% germination inhibition) and late blight disease progression and severity (86 and $77 \%$ disease reduction). The remaining seven preparations showed moderate to low efficiency against tomato late blight. Many local plants from Cameroon have been reported to possess inhibitory properties against various pathogens. Most studies dealing with these compounds, however, were limited to in vitro tests. This is the first report on the activity of plant extracts on $P$. infestans in Cameroon, using tests that are the closest to natural conditions. Despite the inhibitory effects observed, the majority of the extracts tested apparently did not possess enough desirable antifungal properties to use them alone, compared with the synthetic fungicides used as positive controls. Since there is a growing concern by consumers and environmentalists about the heavy reliance on chemicals in plant protection strategies, natural products may be developed as components of an integrated and more sustainable late blight management strategy with a final goal of reduced fungicide usage and production costs in both conventional and organically grown tomato crops. The nine plant-derived products tested are considered less expensive because of their accessibility and high yield. Their association with other well-established disease control practices could lead to effective late blight control.

\section{REFERENCES}

Ameziane N., Boubaker H., Boudyach H., Msanda F., Jilal A., Ait Benaoumar A. (2007) Antifungal activity of Moroccan plants against citrus fruit pathogens, Agron. Sustain. Dev. 27, 273-277.

Berger R.D. (1980) Measuring disease intensity, in: Berger R.D. (Ed.), Proceedings of E.C. Stakman commemorative symposium on crop loss assessment, Publication 7, University of Minnesota, St Paul, USA, pp. 28-31.

Blaeser P., Steiner U. (1999) Antifungal activity of plant extracts against potato late blight (Phytophthora infestans), in: Lyr H., Russel P.E., Dehne H.W. (Eds.), Modern fungicides and antifungal compounds II, 12th International Reinhardsbrunn Symposium, pp. 491-499.

Burkill H.M. (1985) The useful plants of west tropical Africa, Ed. 2, Vol. 1, Royal Botanical Gardens, Kew.

Cable S., Cheek M. (1998) The plants of Mount Cameroon, a conservation checklist, Royal Botanic Gardens, Kew.

Christ U., Mösinger E. (1989) Pathogenesis-related proteins of tomato I: induction by Phytophthora infestans and other biotic and abiotic inducers and correlations with resistance, Physiol. Mol. Plant P. 35, $53-65$.

Cohen Y., Gisi U., Mosinger E. (1991) Systemic resistance of potato plants against Phytophthora infestans induced by unsaturated fatty acids, Physiol. Mol. Plant P. 38, 255-263.

Cutler H.C. (1988) Biologically active natural products: potential use in agriculture, American Chemical Society, USA.

Dales M.J. (1996) A review of plant materials used for controlling insect pests of stored products, Natural Resources Institute, Chatham, UK.

Dorn B., Musa T., Krebs H., Fried P.M., Forrer H.R. (2007) Control of late blight in organic potato production: evaluation of copperfree preparations under field, growth chamber and laboratory conditions, Eur. J. Plant Pathol. 119, 217-240.

Erwin C.D., Ribeiro O.K. (1996) Phytophthora diseases worldwide, APS Press, St-Paul, Minnesota, USA.

Fontem D.A., Olanya O.M., Njualem, B.F. (2004) Reaction of certain Solanaceous and Asteraceous plant species to inoculation with Phytophthora infestans in Cameroon, J. Phytopathol. 152, 331336.

Fontem D.A., Olanya M.O., Tsopmbeng G.R., Owona M.A.P. (2005) Pathogenicity and metalaxyl sensitivity of Phytophthora infestans isolates obtained from garden huckleberry, potato and tomato in Cameroon, Crop Prot. 24, 449-456.

Ghisalberti E.L. (2000) Lantana camara L. (Verbenaceae), Fitoterapia 71, 467-486.

Koona P., Bouda H. (2004) Activity of 2,4,5-trimethoxystyrene from Pachypodanthium staudtii against two stored product pests, Trop. Sci. 44, 120-123.

Lee T.Y., Mizubuti E., Fry W.E. (1999) Genetics of metalaxyl resistance in Phytophthora infestans. Fungal Genet. Biol. 26, 118-130.

Montes-Molina J.A., Luna-Guido M., Ceballos-Ramirez J.M., Fernández-Luqueño F., Espinoza-Paz N., Rincón-Rosales R., Dendooven L., Gutierrez-Miceli F.A. (2008) Effect of 
pest-controlling neem and mata-raton on bean growth, soil $\mathrm{N}$ and soil $\mathrm{CO}_{2}$ emissions, Agron. Sustain. Dev. 28, 187-194.

Mukalazi J.E., Adipala T., Sengooba J.J., Haliza M., Olanya H., Kidanemariam M. (2001) Metalaxyl resistance, mating types and pathogenicity of Phytophthora infestans in Uganda, Crop Prot. 20, 379-388.

Quintanilla P., Rohloff J., Iversen T.H. (2002) Influence of essential oils on Phytophthora infestans, Potato Res. 45, 225-235.

Regnault-Roger C., Philogène B.J.R., Vincent C. (2005) (Eds.) Biopesticides of plant origin, Tec \& Doc Lavoisier, Paris.

Schippers R.R. (2004) Légumes Africains indigènes : présentation des espèces cultivées, Margraf Publishers GmbH, Scientific Books, CTA, Wageningen, Pays-Bas.
Strange R.N. (2003) Introduction to plant pathology, John Wiley and Sons Ltd, UK.

Suassuna N.D., Mafia L.A., Mizubuti E.S.G. (2004) Aggressiveness and host specificity of Brazilian isolates of Phytophthora infestans, Plant Pathol. 53, 405-413.

Thuerig B., Binder A., Boller T., Guyer U., Jiménez S., Rentsch Ch., Tamm L. (2006) An aqueous extract of the dry mycelium of Penicillium chrysogenum induces resistance in several crops under controlled and field conditions, Eur. J. Plant Pathol. 114, 185-197.

Wang S., Hu T., Zhang F., Forrer H.R., Cao K. (2007) Screening for plant extracts to control potato late blight. Front. Agric. China 1, 43-46.

Winteringham F.P.W. (1985) Environment and chemicals in agriculture, Elsevier Applied Science Publishers, London/New York. 